\title{
Demetria terragena gen. nov., sp. nov., a New Genus of Actinomycetes Isolated from Compost Soil
}

\author{
INGRID GROTH,${ }^{1 *}$ P. SCHUMANN,${ }^{2}$ F. A. RAINEY,${ }^{3}$ KARIN MARTIN,${ }^{1}$ BARBARA SCHUETZE, ${ }^{1}$ \\ AND K. AUGSTEN, ${ }^{4}$ \\ Hans-Knöll-Institut für Naturstoff-Forschung e.V., ${ }^{1}$ DSMZ-Deutsche Sammlung von Mikroorganismen und Zellkulturen \\ $\mathrm{GmbH}$, Aussenstelle Jena, ${ }^{2}$ and Institut für Molekulare Biotechnologie e.V., ${ }^{4}$ D-07745 Jena, and \\ Deutsche Sammlung von Mikroorganismen und Zellkulturen GmbH, D-38124 Braunschweig, Germany ${ }^{3}$
}

\begin{abstract}
A novel actinomycete was isolated from compost soil and was studied taxonomically and phylogenetically. Cells of this organism were gram positive, not acid fast, nonmotile, nonsporulating, irregular coccoid to short rod shaped, and microaerophilic. The cell wall peptidoglycan contained lysine and was cross-linked via an L-Lys $\leftarrow L-S e r \leftarrow D-A s p$ interpeptide bridge. The major menaquinone was $M K-8\left(H_{4}\right)$. The polar lipids were phosphatidylinositol, phosphatidylglycerol, diphosphatidylglycerol, phosphatidylethanolamine, and two unknown phospholipids. Mycolic acids were absent. The cellular fatty acid profile was complex, with large amounts of saturated and monounsaturated straight-chain acids and smaller amounts of iso and anteiso branched-chain acids. The $\mathrm{G}+\mathrm{C}$ content of the DNA was $66 \mathrm{~mol} \%$. Comparative $16 \mathrm{~S}$ ribosomal DNA studies revealed that strain $\mathrm{HKI} 0089^{\mathrm{T}}$ represents a novel lineage within Actinobacteria (32) distinct from all previously described genera and most closely related to members of the genera Kytococcus, Dermacoccus, and Dermatophilus of the family Dermatophilaceae. On the basis of our results, we suggest that strain HKI 0089 should be classified in a new genus and species, for which we propose the name Demetria terragena. The type strain and the only strain of the genus and species is HKI 0089 (DSM 11295).
\end{abstract}

In a program aimed at isolating rare or novel actinomycetes as a potential resource of bioactive secondary metabolites, isolates were studied by morphological, physiological, and chemotaxonomic methods. It is generally accepted that the results of chemotaxonomic analyses of cellular compounds are extremely useful for delimiting genera within the order Actinomycetales $(6,30)$. In 115 of 900 isolates of actinomycetes originating from 33 soil samples from different geographic regions, lysine was found to be the diagnostic diamino acid in the peptidoglycan. Most of these strains could be identified as members of the genera Arthrobacter, Kocuria, Micrococcus, Nesterenkonia, Oerskovia, Promicromonospora, and Microbacterium. We focused our interest on two of these isolates commonly containing lysine and having $\mathrm{MK}-8\left(\mathrm{H}_{4}\right)$ as the main menaquinone but differing remarkably from each other by morphological, physiological, and further biochemical properties. One of these isolates from a sample of soda soil has been recently described as a member of the new genus and species Bogoriella caseilytica (13). In this paper, we describe the taxonomic and phylogenetic characterization of the second isolate, HKI $0089^{\mathrm{T}}$, with the combination of the cell wall diamino acid lysine and the menaquinone MK-8 $\left(\mathrm{H}_{4}\right)$. On the basis of our results, we suggest that this strain should be assigned to a new genus and species. The name Demetria terragena is proposed for this organism, which has been deposited in the German Collection of Microorganisms and Cell Cultures as strain DSM $11295^{\mathrm{T}}$. Strain HKI 0089 is the type strain and the only strain of $D$. terragena.

\section{MATERIALS AND METHODS}

Bacterial strain and cultural conditions. Strain $\mathrm{HKI} 0089^{\mathrm{T}}$ was isolated from a sample of frozen compost soil obtained near Jena, Germany, at a depth of about $10 \mathrm{~cm}$. The organism was isolated by dilution plating on nutrient agar

* Corresponding author. Mailing Address: Hans-Knöll-Institut für Naturstoff-Forschung, Beutenbergstrasse 11, D-07745 Jena, Germany. Phone: 049-3641-656666. Fax: 049-3641-656600. E-mail: igroth@leutra imb-jena.de. containing (per liter) $20.0 \mathrm{~g}$ of peptone, a pancreatic digest (meat or fish), $5.0 \mathrm{~g}$ of $\mathrm{NaCl}$, and $12.0 \mathrm{~g}$ of agar. For morphological and chemotaxonomic studies, strain HKI $0089^{\mathbf{T}}$ was cultivated in liquid or on solidified rich (R) medium (36), peptone-yeast extract-brain heart infusion medium (37), and Bacto tryptic soy broth (Difco Laboratories, Detroit, Mich.).

Morphological and physiological characteristics. Cell morphology was examined by phase-contrast microscopy (Olympus BH-2 microscope; Tokyo, Japan). Motility was studied with a hanging drop. Cell dimensions were measured with an ocular $(\times 10)$ and objective micrometer $(\times 100 / 1.25)$ device. Gram staining was performed according Hucker's modification (4) with reagents produced by bioMerieux (Marcy l'Etoile, France). Ninety-six percent (wt/vol) ethanol was substituted for the decolorizer of the Gram staining. Acid fastness was determined by Ziehl-Neelsen staining (18). Colony morphology was studied with a stereo microscope (Olympus SZ 11). For scanning electron microscopy, a 48-hold culture of strain HKI $0089^{\mathrm{T}}$ from R medium was suspended in a phosphatebuffered salt solution. The cells were fixed with $0.5 \%$ glutaraldehyde $(\mathrm{pH} 7.4)$, washed several times, and dehydrated in a series of increasing ethanol concentrations. After being sputter coated with gold-palladium, the cells were observed with a scanning electron microscope (JSM $6300 \mathrm{~F}$; JEOL, Tokyo, Japan) at $3 \mathrm{kV}$ at a working distance of $7 \mathrm{~mm}$. Tolerance to $\mathrm{NaCl}$ was tested at concentrations of between 2 and $14 \%(\mathrm{wt} / \mathrm{vol})$ in combination with $\mathrm{R}$ medium. The effect of temperature on growth was tested at 28 and $37^{\circ} \mathrm{C}$ on R medium. Oxygen requirements were studied with Generbag microaer and Generbag anaer incubation systems (bioMerieux) on $\mathrm{R}$ agar plates. Acid production from carbohydrates was examined with the oxidation-fermentation (O-F) medium of Hugh and Leifson (15) as recommended by Lanyi (18). Enzyme activities from a 72-h-old culture on solid $\mathrm{R}$ medium were examined with API ZYM galleries (bioMerieux). Utilization of organic acids was studied with the medium described by Cowan and Steel (4) by adding the sodium salts of the organic acids to a final concentration of $0.2 \%$ (wt/vol). In the case of tartrate, the potassium salt was added. Nitrate reduction; urease activity; indole production; hydrogen sulfide production; hydrolysis of Tween 80 , esculin, and gelatin; and the methyl red and Voges-Proskauer reactions were examined as described by Lanyi (18). In the case of nitrate reduction, the reagents NIT 1 and NIT 2 (bioMerieux) were used. Indole production and methyl red and Voges-Proskauer reactions were examined by using Kovacs reagent and reagents VP 1 and VP 2 (bioMerieux), respectively. Catalase production and hydrolysis of casein and potato starch were studied by the methods of Gledhill and Casida (9). Decomposition of adenine, hypoxanthine, xanthine, and tyrosine was studied by the method recommended by Gordon et al. (11). Cytochrome $c$ oxidase activity was studied by monitoring the oxidation of $N, N, N^{\prime}, N^{\prime}$-tetramethyl-phenylene-diamine dihydrochloride on Dryslide oxidase (Difco). Hydrolysis of hippurate was tested on hippurate agar (4). Susceptibility to antibiotics was studied by placement of antibiotic discs (Oxoid) on Bacto nutrient agar plates seeded with suspensions of strain HKI $0089^{\mathrm{T}}$

Cell wall analysis. Purified cell wall preparations were obtained by the method of Schleifer and Kandler (28). The amino acids and peptides in cell wall hydro- 
lysates were analyzed by two-dimensional ascending thin-layer chromatography on cellulose plates with the solvent systems described in reference 28 . The amino-terminal amino acid of the interpeptide bridge was determined by dinitrophenylation as described by Schleifer (27). Whole-cell sugars were determined as alditol acetates by gas chromatography and gas chromatography-mass spectrometry as described previously (14). The molar ratios of amino acids were determined by gas chromatography and gas chromatography-mass spectrometry of $\mathrm{N}$-heptafluorobutyryl amino acid isobutyl esters (20). Analysis of enantiomers of cell wall amino acids was performed by gas chromatography of $N$-pentafluoropropionyl amino acid isopropyl esters (8) on an L-Chirasil-Val column ( $25 \mathrm{~m}$ by $0.25 \mathrm{~mm}$ [inside diameter]; Macherey-Nagel, Düren, Germany) with $\mathrm{He}$ as the carrier gas at a linear velocity of $200 \mathrm{~mm} / \mathrm{s}$ and at a temperature programmed from $80^{\circ} \mathrm{C}$ to $190^{\circ} \mathrm{C}$ at a rate of $2^{\circ} \mathrm{C} / \mathrm{min}$. The instruments used for gas chromatography and gas chromatography-mass spectrometry were specified previously (14). The glycolate content of bacterial cell walls was determined by the colorimetric method of Uchida and Aida (35).

Lipid analysis. Cellular fatty acid methyl esters obtained from cells grown in Bacto tryptic soy broth at $28^{\circ} \mathrm{C}$ by the method described by Stead et al. (33) were separated by gas chromatography (14) and identified as described previously (29). Menaquinones were extracted as described by Collins et al. (3) and were analyzed by high-performance liquid chromatography (14). Polar lipids extracted by the method of Minnikin et al. (24) were identified by two-dimensional thinlayer chromatography and by being sprayed with specific reagents (2). The absence of mycolic acids was demonstrated by thin-layer chromatography (23)

DNA base composition. DNA was isolated, and its $\mathrm{G}+\mathrm{C}$ content was determined by high-performance liquid chromatography of deoxyribonucleosides as described previously (14).

$16 \mathrm{~S}$ rDNA sequence determination and phylogenetic analysis. Genomic DNA extraction, PCR-mediated amplification of the $16 \mathrm{~S}$ ribosomal DNA (rDNA), and sequencing of the PCR products were performed as described previously (25) The sequence reactions were electrophoresed with a model 373A automatic DNA sequencer (Applied Biosystems, Foster City, Calif.). The 16S rDNA sequences were manually aligned with the sequences of members of the Actinobacteria by using the ae2 editor (21). Evolutionary distances were calculated by the method of Jukes and Cantor (16). Phylogenetic dendrograms were reconstructed with treeing algorithms contained in the PHYLIP package (7).

Nucleotide sequence accession number. The $16 \mathrm{~S}$ rDNA sequence determined in this study has been deposited in the EBI database under accession no. Y14152. The accession numbers of the reference strains used in the phylogenetic analyses are as follows: Anthrobacter globiformis DSM 20124 ${ }^{\mathrm{T}}, \mathrm{M} 23411 ;$ B. caseilytica $\mathrm{HKI}$ $0088^{\mathrm{T}}$, Y09911; Brachybacterium faecium DSM 4810 ${ }^{\mathrm{T}}, \mathrm{X} 83810 ;$ Brevibacterium linens DSM 20425 ${ }^{\mathrm{T}}$ X777451; Cellulomonas flavigena DSM 20109 ${ }^{\mathrm{T}}$, X83799; Clavibacter michiganense subsp. michiganense DSM $46364^{\mathrm{T}}$, X77435; Dermabacter hominis DSM 7083 ${ }^{\mathrm{T}}$, X91034; Dermacoccus nishinomiyaensis DSM 20448 ${ }^{\mathrm{T}}$, X87757; Dermatophilus congolensis ATCC 14637 ${ }^{\mathrm{T}}$, M59057; Jonesio denitrificans DSM 20603 $3^{\mathrm{T}}$, X83811; Kocuria rosea DSM 20447 ${ }^{\mathrm{T}}$, X87756; Kytococcus sedentarius DSM $20547^{\mathrm{T}}$, X87755; Microbacterium lacticum DSM $20427^{\mathrm{T}}$, X77441; Micrococcus luteus ATCC 381, M38242; Nesterenkonia halobia DSM $20541^{\mathrm{T}}$, X80747; Renibacterium salmoninarum ATCC 33209T, X51601; Rothia dentocariosa ATCC 17931 ${ }^{\mathrm{T}}$, M59055; Sanguibacter keddieii ST-74 ${ }^{\mathrm{T}}$, X79450; and Terrabacter tumescens DSM $20308^{\mathrm{T}}$, X83812.

\section{RESULTS}

Morphological and cultural characteristics. Strain HKI $0089^{\mathrm{T}}$ formed circular entire convex smooth colonies that were white to yellow on $\mathrm{R}$ medium. Cells were gram-positive, nonacid fast, irregular coccoid to short rod shaped, and varied in size $(0.8$ by 1.2 to 0.8 by $2.2 \mu \mathrm{m})$. They occurred as single cells, pairs, short chains, or irregular clusters (Fig. 1). Scanning electron micrographs revealed the existence of filopodia at the bottom sides of the cells (Fig. 2). We assume that these structures are probably responsible for the adhesion of the cells to the substrate and/or for the communication between neighbouring cells, provided the distance between the cells is less than $1 \mu \mathrm{m}$. Further studies are necessary to prove this assumed function and to clarify these structures. Up to now, comparable external cell structures in actinomycetes were only reported for the alkaliphilic species $B$. caseilytica (13).

Strain HKI $0089^{\mathrm{T}}$ grew well on complex organic media at $28^{\circ} \mathrm{C}$ under aerobic and microaerophilic conditions. At $37^{\circ} \mathrm{C}$ and under anaerobic conditions, no growth occurred on $\mathrm{R}$ medium. The addition of $\mathrm{NaCl}$ to $\mathrm{R}$ medium stimulated growth in concentrations of 4 to $6 \%$ (wt/vol). Beginning with a concentration of $8 \%(\mathrm{wt} / \mathrm{vol}) \mathrm{NaCl}$, a decrease in growth was

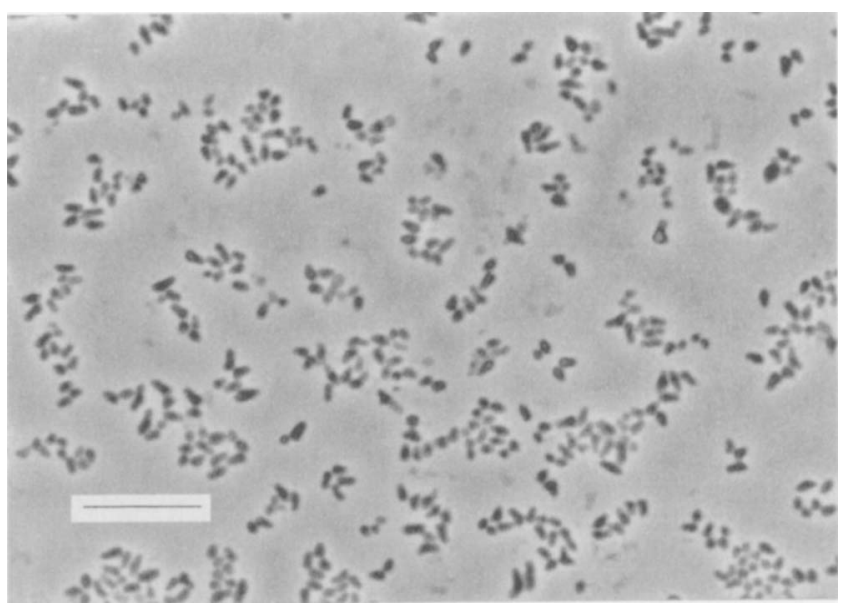

FIG. 1. Micrograph of strain HKI $0089^{\mathrm{T}}$ grown on solid R medium at $28^{\circ} \mathrm{C}$ for $48 \mathrm{~h}$. Bar, $10 \mu \mathrm{m}$.

observed, and at a concentration of $14 \%(\mathrm{wt} / \mathrm{vol})$, no growth occurred.

Physiological characteristics. The physiological properties of strain HKI $0089^{\mathbf{T}}$ are listed in the formal description of the strain at the end of the Discussion section.

Chemotaxonomic characteristics. The peptidoglycan of strain HKI $0089^{\mathbf{T}}$ contained Lys, Ala, Asp, Glu, and Ser in a molar ratio of $0.8: 1.8: 1.2: 1.0: 0.8$, respectively. Asp was found to be the amino-terminal amino acid of the interpeptide bridge. The enantiomeric analysis of cell wall amino acids resulted in the detection of L-Lys, D-Ala and L-Ala (molar ratio, 1:1.3), D-Asp, D-Glu, and L-Ser. From these results and from twodimensional thin-layer chromatographic peptide patterns of partial hydrolysates of cell walls, it was concluded that strain HKI $0089^{\mathrm{T}}$ represents variation A11.36 (5) of the peptidoglycan type A4 $\alpha$ (27) with an L-Lys $\leftarrow$ L-Ser $\leftarrow$ D-Asp interpeptide bridge. The acyl type is acetyl. Galactose was found only as whole-cell sugar. The polar lipid pattern consisted of phosphatidylinositol, phosphatidylglycerol, diphosphatidylglycerol,

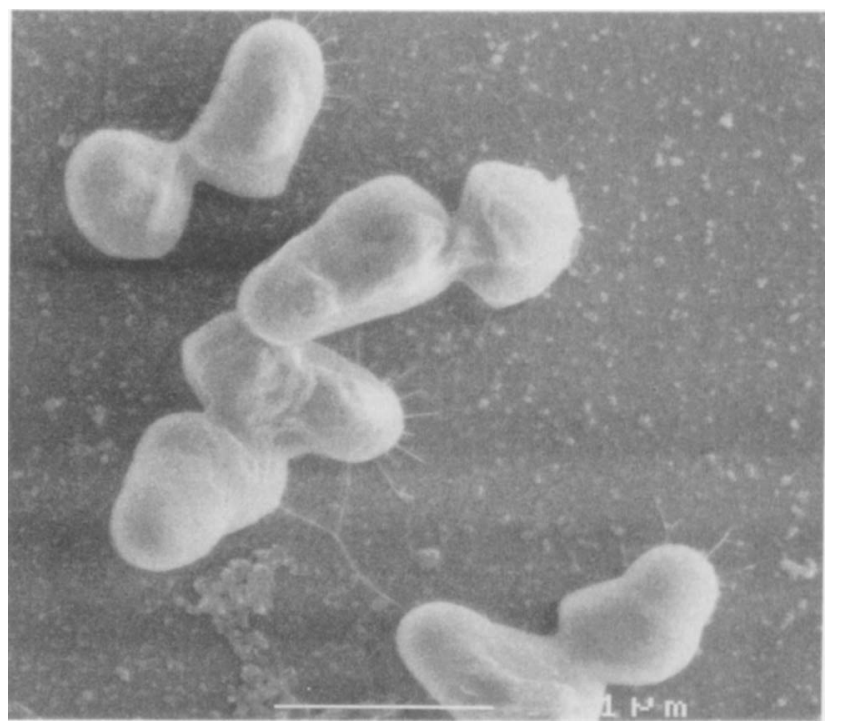

FIG. 2. Scanning electron micrograph of cells from a 48-h-old culture of strain HKI $0089^{\mathrm{T}}$ grown at $28^{\circ} \mathrm{C}$ on solid R medium. Bar, $1 \mu \mathrm{m}$. 


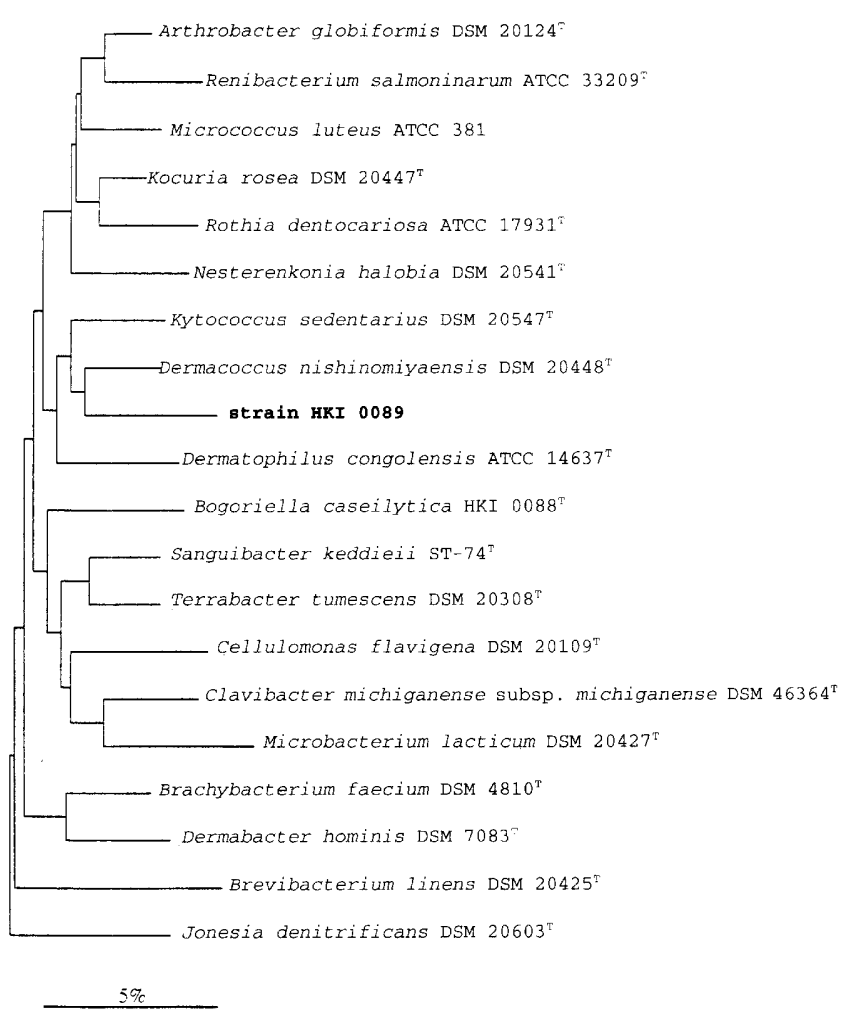

FIG. 3. 16S rDNA sequence-based phylogenetic dendrogram reconstructed from evolutionary distances by the neighbor-joining method (26). Scale bar, 5 inferred nucleotide substitutions per 100 nucleotides.

phosphatidylethanolamine, and two unknown phospholipids. The complex fatty acid profile was characterized by the occurrence of large amounts of saturated and monounsaturated straight-chain acids as well as smaller amounts of iso and anteiso branched-chain acids. The percentages fatty acid composition of strain HKI $0089^{\mathrm{T}}$ are as follows: $\mathrm{C}_{14: 0}, 0.5$; $\mathrm{i}-\mathrm{C}_{15: 0}$, $1.9 ; \mathrm{C}_{15: 0}, 1.5 ; \mathrm{i}-\mathrm{C}_{16: 0}, 7.4 ; \mathrm{C}_{16: 0}, 9.8 ; \mathrm{C}_{16: 1}, 3.4 ; \mathrm{i}-\mathrm{C}_{17: 0}, 6.2$; ai- $\mathrm{C}_{17: 0}, 9.9 ; \mathrm{C}_{17: 0}, 13.9 ; \mathrm{C}_{18: 0}, 14.2 ; \mathrm{C}_{18: 1}, 25.2 ; \mathrm{t}_{19}, 1.8$; and $\mathrm{C}_{19: 0}, 2.2$. (Note that $\mathrm{C}_{16: 0}$ is hexadecanoic acid, $\mathrm{C}_{18: 1}$ is octadecanoic acid, $\mathrm{i}-\mathrm{C}_{15: 0}$ is 13-methyl tetradecanoic acid, ai- $\mathrm{C}_{17: 0}$ is 14-methyl hexadecanoic acid, and $t_{19}$ is 10 -methoxyl octadecanoic acid.) Mycolic acids were not present. The only menaquinone was MK-8( $\left(\mathrm{H}_{4}\right)$. The $\mathrm{G}+\mathrm{C}$ content of the DNA of strain HKI $0089^{\mathrm{T}}$ was $66 \mathrm{~mol} \%$.

16S rDNA sequence analysis. An almost complete 16S rDNA sequence comprising 1,476 nucleotides ( $>95 \%$ of the Escherichia coli sequence (1) was determined for strain HKI $0089^{\mathrm{T}}$. The phylogenetic dendrogram shown in Fig. 3 was reconstructed from evolutionary distances $(16)$ by the neighborjoining method (26). A total of 1,315 nucleotides present in all strains between positions 41 and 1452 (E. coli positions [1]) was used for this analysis. The phylogenetic dendrogram (Fig. 3) shows that strain HKI $0089^{\mathrm{T}}$ falls within the radius of the order Actinomycetales. Its closest phylogenetic neighbors are the genera of the family Dermatophilaceae, i.e., Kytococcus, Dermacoccus, and Dermatophilus. Strain HKI $0089^{\mathrm{T}}$ shows $16 \mathrm{~S}$ rDNA sequence similarities of $93.8,92.8$, and $90.8 \%$ to the sequences of $D$. nishinomiyaensis, $K$. sedentarius, and $D$. congolensis, respectively, when compared directly with these taxa. The grouping of strain HKI $0089^{\mathrm{T}}$ within the cluster comprising the family Dermatophilaceae is supported by the presence of all signature nucleotides previously defined for the family Dermatophilaceae (32).

\section{DISCUSSION}

Within the peptidoglycan types of the actinomycetes, those with lysine as the diagnostic diamino acid are the most numerous (5). It is clear that lysine is mainly associated with coryneform and nocardioform morphologies. In sporoactinomycetes, lysine is found only in the genera Catenuloplanes (38) and Couchioplanes (34). To date, all known lysine-containing genera of actinomycetes were found to belong to group A peptidoglycan, with the exception of the genus Microbacterium, which possesses the group B peptidoglycan (28).

Diamino acids in combination with menaquinone types are extremely useful in differentiating genera of the coryneform bacteria from each other. Menaquinone patterns occurring together with lysine comprise partially saturated and unsaturated menaquinones. The number of isoprene units of unsaturated menaquinones may vary in a range from 6 to 12 . The menaquinone type $\mathrm{MK}-8\left(\mathrm{H}_{4}\right)$ and the occurrence of lysine up to now have only been reported for the actinomycete $B$. case $i$ lytica (13). The menaquinone $\mathrm{MK}-8\left(\mathrm{H}_{4}\right)$ has been described, however, for $\mathrm{G}+\mathrm{C}$-rich bacteria in combination with LL-diaminopimelic acid $\left(\mathrm{A}_{2} \mathrm{pm}\right)$ (Aeromicrobium [29], Nocardioides [29], Terrabacter [29]) and with meso- $\mathrm{A}_{2} \mathrm{pm}$ in the peptidoglycan (Dermatophilus [31], Nocardia [19], Pseudonocardia [19], Saccharomonospora [12], and Saccharopolyspora [19], Pseudonocardia [19], Saccharomonospora [12], and Saccharopolyspora [19] and the coryneform genera Janibacter [22] and Microsphaera [22]).

On the basis of the chemotaxonomic characteristics (Table 1 ), especially because of the rare structure of the peptidoglycan with the L-Lys $\leftarrow \mathrm{L}-\mathrm{Ser} \leftarrow \mathrm{D}$-Asp interpeptide bridge in combination with the menaquinone MK- $8\left(\mathrm{H}_{4}\right)$, strain HKI $0089^{\mathrm{T}}$ can be clearly differentiated from its phylogenetic neighbors (Fig. 3 ) and from all of the genera mentioned above with lysine or menaquinone type $\mathrm{MK}-8\left(\mathrm{H}_{4}\right)$. The results of the $16 \mathrm{~S}$ rDNA sequence comparisons clearly demonstrate the distinct position of strain HKI $0089^{\mathrm{T}}$ within the radius of the actinomycetes. This is seen in the phylogenetic dendrogram, the range of 16S rDNA sequence similarity values to the closest relatives within the family Dermatophilaceae, and the presence of all signature nucleotides as defined for this family. Strain HKI $0089^{\mathrm{T}}$ differs significantly from the distantly related genus Dermatophilus in the $\mathrm{G}+\mathrm{C}$ content of the DNA, the diagnostic diamino acid of the peptidoglycan, the composition of fatty acids and phospholipids, the lack of diagnostic cell sugars, and the morphological and physiological properties. The closest phylogenetic neighbor of HKI $0089^{\mathrm{T}}$ is $D$. nishinomiyanensis, which differs from our isolate in the amino acids of the interpeptide bridge, in having menaquinone type $\mathrm{MK}-8\left(\mathrm{H}_{4}\right)$, and in lacking the characteristic phospholipid phosphatidylethanolamine, as well as in fatty acid composition. Furthermore, differences in morphology and in physiological properties such as the presence of oxidase and urease, the toxic effect of more than $7 \%$ (wt/vol) $\mathrm{NaCl}$ in the culture medium, the good growth at $37^{\circ} \mathrm{C}$, and obvious differences in the utilization of carbon sources justify its separation from HKI $0089^{\mathrm{T}}$ on the genus level. Pronounced differences in chemotaxonomic and physiological characteristics were found equally between HKI $0089^{\mathrm{T}}$ and $K$. sedentarius. Therefore, we concluded that on the basis of our results and remarkable differences in taxonomic characteristics between HKI $0089^{\mathrm{T}}$ and all genera of actinomycetes, this organism should be assigned to a new genus and species, for which the name Demetria terragena is proposed. 
TABLE 1. Characteristics of the phylogenetic neighbors of HKI $0089^{\mathrm{T} a}$

\begin{tabular}{|c|c|c|c|c|c|c|c|}
\hline Taxon & Morphology & $\begin{array}{l}\text { Peptidoglycan } \\
\text { (group) }\end{array}$ & Major menaquinone(s) & Fatty acids & Polar lipids & $\begin{array}{l}\text { Mycolic } \\
\text { acids }\end{array}$ & $\begin{array}{l}\mathrm{G}+\mathrm{C} \text { content } \\
\quad(\mathrm{mol} \%)\end{array}$ \\
\hline HKI $0089^{\mathrm{T}}$ & $\begin{array}{l}\text { Coccoid, short rods, } \\
\text { nonsporulating }\end{array}$ & $\begin{array}{l}\text { Lys, MCA, DCA } \\
\text { (A4 } 4)\end{array}$ & MK- $8\left(\mathrm{H}_{4}\right)$ & $\mathrm{S}, \mathrm{U}, \mathrm{A}, \mathrm{I}$ & $\begin{array}{l}\text { PI, PG, DPG, } \\
\text { PE, PL }\end{array}$ & - & 66 \\
\hline Dermacoccus $^{b, c}$ & $\begin{array}{l}\text { Coccoid, nonsporu- } \\
\text { lating }\end{array}$ & $\begin{array}{l}\text { Lys-MCA, DCA } \\
(\mathrm{A} 4 \alpha)\end{array}$ & $\mathrm{MK}-8\left(\mathbf{H}_{2}\right)$ & $\mathrm{S}, \mathrm{A}, \mathrm{I}$ & DPG, PG, PI & - & $66-71$ \\
\hline Kytococcus $s^{b, c}$ & $\begin{array}{l}\text { Coccoid, nonsporu- } \\
\text { lating }\end{array}$ & Lys-DCA (A4 $\alpha)$ & MK-8, MK-9, MK-10 & $(\mathrm{S}), \mathrm{A}, \mathrm{I}$ & DPG, PG, PI & - & $68-69$ \\
\hline Dermatophilus ${ }^{d, e}$ & $\begin{array}{l}\text { Mycelium, motile } \\
\text { spores }\end{array}$ & meso- $\mathrm{A}_{2} \mathrm{pm}(\mathrm{A} 1 \gamma)$ & MK- $8\left(\mathrm{H}_{4}\right)$ & $\mathrm{S}, \mathrm{U}$ & PG, DPG, PI & $\mathrm{ND}^{\prime}$ & $57-59$ \\
\hline
\end{tabular}

a MCA, monocarboxylic amino acid; DCA, dicarboxylic amino acid; S, straight-chain saturated; U, monounsaturated; A, anteiso methyl branched; I, iso methyl branched; DPG, diphosphatidylglycerol; PE, phosphatidylethanolamine; PG, phosphatidylglycerol; PI, phosphatidylinositol; PL, unknown phospholipid(s).

${ }^{b}$ Data from reference 10 .

${ }^{c}$ Data from reference 17.

${ }^{d}$ Data from reference 30.

${ }^{e}$ Data from reference 31

${ }^{f} \mathrm{ND}$, not determined.

Description of Demetria gen. nov. Demetria (De.me.tria Gr. M. n. Demeter, Greek female god of agriculture and wives; -ia, M.L. fem., Demetria, a bacterium being responsible for fertility). Cells are gram positive; not acid fast; irregular coccoid to short rod shaped ( 0.8 to 1.2 by 0.8 to $3.0 \mu \mathrm{m}$ ); and occur singly, in pairs, in short chains, or in small irregular clusters. Nonmotile and nonsporulating. Colonies are circular, convex, entire, smooth, 1 to $3 \mathrm{~mm}$ in diameter, and white to pale yellow. Aerobic to microaerophilic. Catalase positive, oxidase negative. The cell wall peptidoglycan contains lysine as the characteristic diamino acid and a dicarboxylic amino acid in the interpeptide bridge. The acyl type is acetyl. Phospholipids are phosphatidylinositol, phosphatidylglycerol, diphosphatidylglycerol, phosphatidylethanolamine, and two unknown phospholipids. Mycolic acids are absent. The cellular fatty acid profile is complex, with saturated and monounsaturated straight-chain acids, and iso and anteiso branched-chain acids. The menaquinone type is MK-8 $\left(\mathrm{H}_{4}\right)$. The $\mathrm{G}+\mathrm{C}$ content of the DNA is 66 mol\%. Phylogenetically, this genus is a member of the family Dermatophilaceae (32). The type species is D. terragena.

Description of $D$. terragena sp. nov. $D$. terragena (ter.ra.gen.a L. n. terra, soil; L. suffix gena, origin; M.L. n. terragena, coming from soil). Cells are gram positive; not acid fast; irregular coccoid to short rod shaped ( 0.8 to 1.2 by 0.8 to $3.0 \mu \mathrm{m})$; and occur singly, in pairs, in short chains, or in small irregular clusters. Nonmotile and nonsporulating. Colonies are circular, convex, entire, smooth, 1 to $3 \mathrm{~mm}$ in diameter, and white to pale yellow. Aerobic to microaerophilic. Catalase positive, oxidase negative. Acids are produced from D-fructose, D-galactose, D-glucose, glycerol, D-mannitol, D-mannose, and D-ribose. No acid production from L-arabinose, D-cellobiose, dextrin, D-glucitol, inulin, lactose, maltose, D-raffinose, L-rhamnose, salicin, sucrose, potato starch, trehalose, and D-xylose. Acetate, aconitate, citrate, malate, and succinate are utilized as carbon sources; benzoate, formate and DL-tartrate are not utilized. Nitrate is not reduced to nitrite, catalase and hydrogen sulfide are produced, and oxidase and indole are not. Methyl red and Voges-Proskauer reactions are negative. Casein, potato starch, tyrosine, xanthine, and Tween 80 are decomposed; adenine, esculin, gelatin, hippurate, hypoxanthine, and urea are not. $\mathrm{NaCl}$ in combination with $\mathrm{R}$ medium is well tolerated at concentrations of $2,4,6$, and $8 \%$ (wt/vol). Growth is weak at 10 and $12 \% \mathrm{NaCl}$, and there is no growth at $14 \% \mathrm{NaCl}$. The optimal growth temperature is $28^{\circ} \mathrm{C}$. Cells are susceptible to ampicillin $(10 \mu \mathrm{g})$, chloramphenicol $(30 \mu \mathrm{g})$, ciprofloxacin $(5$ $\mu \mathrm{g})$, erythromycin $(15 \mu \mathrm{g})$, gentamicin $(10 \mu \mathrm{g})$, kanamycin $(30$ $\mu \mathrm{g}$ ), lincomycin (weakly susceptible [2 $\mu \mathrm{g}]$ ), neomycin $(30 \mu \mathrm{g})$, nitrofuran $(300 \mu \mathrm{g})$, oxacillin (weakly susceptible [5 $\mu \mathrm{g}]$ ), oxytetracycline $(30 \mu \mathrm{g})$, penicillin $\mathrm{G}(2 \mathrm{IU})$, polymyxin B (300 $\mathrm{IU})$, rifampin $(2 \mu \mathrm{g})$, and streptomycin $(10 \mu \mathrm{g})$. Cells are resistant to sulfonamide $(300 \mu \mathrm{g})$. The peptidoglycan is of the A4 $\alpha$ type, with $\mathrm{L}$-Lys $\leftarrow \mathrm{L}-\mathrm{Ser} \leftarrow \mathrm{D}$-Asp in the interpeptide bridge. The fatty acid pattern is complex, with saturated and monounsaturated straight-chain acids and smaller amounts of iso and anteiso branched-chain acids. According to the API ZYM enzyme assay, HKI $0089^{\mathrm{T}}$ is positive for alkaline phosphatase, chymotrypsin, esterase lipase $\left(\mathrm{C}_{8}\right)$, leucine arylamidase, phosphatase acid, naphthol-AS-BI-phosphohydrolase, and $\alpha$-glucosidase; weakly positive for esterase $\left(C_{4}\right)$, lipase $\left(\mathrm{C}_{14}\right)$, valine arylamidase, trypsin, and $\alpha$-mannosidase; and negative for cystine arylamidase, $\alpha$-galactosidase, $\beta$-galactosidase, $\beta$-glucuronidase, $\beta$-glucosidase, $N$-acetyl- $\beta$-glucosamidase, and $\alpha$-fucosidase. The $\mathrm{G}+\mathrm{C}$ content of the DNA is 66 mol\%. The habitat is soil. The type strain is HKI 0089, which has been deposited in the German Collection of Microorganisms and Cell Cultures as strain DSM 11295.

\section{ACKNOWLEDGMENTS}

This work was supported by grant $0310591 \mathrm{~A}$ from the Bundesministerium für Bildung, Wissenschaft, Forschung und Technologie, Germany.

We acknowledge Regine Vettermann for critical review of the manuscript. We thank Christiane Weigel and Carmen Schult for excellent technical assistance.

\section{REFERENCES}

1. Brosius, J., M. L. Palmer, P. J. Kennedy, and H. F. Noller. 1978. Complete nucleotide sequence of the 16S ribosomal RNA gene from Escherichia coli. Proc. Natl. Acad. Sci. USA 75:4801-4805.

2. Collins, M. D., and D. Jones. 1980. Lipids in the classification and identification of coryneform bacteria containing peptidoglycans based on 2,4-diaminobutyric acid. J. Appl. Bacteriol. 48:459-470

3. Collins, M. D., T. Pirouz, M. Goodfellow, and D. E. Minnikin. 1977. Distribution of menaquinones in actinomycetes and corynebacteria. J. Gen. Microbiol. 100:221-230.

4. Cowan, S. T., and K. J. Steel. 1965. Manual for the identification of medical bacteria. Cambridge University Press, Cambridge, United Kingdom.

5. DSM-Deutsche Sammlung von Mikroorganismen und Zellkulturen GmbH. 1993. Catalogue of strains, 5th ed. DSM-Deutsche Sammlung von Mikroorganismen und Zellkulturen $\mathrm{GmbH}$, Braunschweig, Germany.

6. Embley, T. M., and E. Stackebrandt. 1994. The molecular phylogeny and systematics of the actinomycetes. Annu. Rev. Microbiol. 48:257-289.

7. Felsenstein, J. 1993. PHYLIP (phylogenetic inference package) version 3.5.1. Department of Genetics, University of Washington, Seattle.

8. Frank, H., A. Rettenmeier, H. Weicker, G. J. Nicholson, and E. Bayer. 1980. 
A new gas chromatographic method for determination of amino acid levels in human serum. Clin. Chim. Acta 105:201-211.

9. Gledhill, W. E., and L. E. Casida, Jr. 1969. Predominant catalase-negative soil bacteria. III. Agromyces, gen. n., microorganisms intermediary to Actinomyces and Nocardia. Appl. Microbiol. 18:340-349.

10. Gordon, M. A. 1989. Genus Dermatophilus Van Saceghem 1915, p. 2409 2410. In S. T. Williams, M. E. Sharpe, and J. G. Holt (ed.), Bergey's manual of systematic bacteriology, vol. 4. The Williams \& Wilkins Co., Baltimore, Md.

11. Gordon, R. E., D. A. Barnett, J. E. Handerhan, and C. H.-N. Pang. 1974. Nocardia coeliaca, Nocardia autotrophica, and the nocardin strain. Int. J. Syst. Bacteriol. 24:54-63.

12. Greiner-Mai, E., F. Korn-Wendisch, and H. J. Kutzner. 1988. Taxonomic revision of the genus Saccharomonospora and description of Saccharomonospora glauca sp. nov. Int. J. Syst. Bacteriol. 38:398-405.

13. Groth, I., P. Schumann, F. A. Rainey, K. Martin, B. Schuetze, and K. Augsten. 1997. Bogoriella caseilytica gen. nov., sp. nov., a new alkaliphilic coryneform bacterium from a soda lake in Africa. Int. J. Syst. Bacteriol. 47:788-794.

14. Groth, I., P. Schumann, N. Weiss, K. Martin, and F. A. Rainey. 1996. Agrococcus jenensis gen. nov., sp. nov., a new genus of actinomycetes with diaminobutyric acid in the cell wall. Int. J. Syst. Bacteriol. 46:234-239.

15. Hugh, R., and E. Leifson. 1953. The taxonomic significance of fermentative versus oxidative metabolism of carbohydrates by various gram negative bacteria. J. Bacteriol. 66:24-26.

16. Jukes, T. H., and C. R. Cantor. 1969. Evolution of protein molecules, p. 21-132. In H. N. Munro (ed.), Mammalian protein metabolism. Academic Press, New York, N.Y.

17. Kocur, M. 1986. Genus Micrococcus Cohn 1872, p. 1004-1008. In P. H. A. Sneath, N. S. Mair, M. E. Sharpe, and J. G. Holt (ed.), Bergey's manual of systematic bacteriology, vol. 2. The Williams \& Wilkins Co., Baltimore, Md.

18. Lanyi, B. 1987. Classical and rapid identification methods for medically important bacteria. Methods Microbiol. 19:1-67.

19. Lechevalier, H. A. 1986 . Nocardioforms, p. 1458-1459. In P. H. A. Sneath, N. S. Mair, M. E. Sharpe, and J. G. Holt (ed.), Bergey's manual of systematic bacteriology, vol. 2. The Williams \& Wilkins Co., Baltimore, Md.

20. MacKenzie, S. L. 1987. Gas chromatographic analysis of amino acids as the $N$-heptafluorobutyryl isobutyl esters. J. Assoc. Off. Anal. Chem. 70:151-160.

21. Maidak, B. L., N. Larsen, M. J. McCaughey, R. Overbeek, G. J. Olsen, K. Fogel, J. Blandy, and C. R. Woese. 1994. The ribosomal database project. Nucleic Acids Res. 22:3485-3487.

22. Martin, K., P Schumann, F. A. Rainey, B. Schuetze, and I. Groth. 1997. Janibacter limosus gen. nov., sp. nov., a new actinomycete with meso-diaminopimelic acid in the cell wall. Int. J. Syst. Bacteriol. 47:529-534.

23. Minnikin, D. E., L. Alshamaony, and M. Goodfellow. 1975. Differentiation of Mycobacterium, Nocardia, and related taxa by thin-layer chromatographic analysis of whole-organism methanolysates. J. Gen. Microbiol. 88:200-204.

24. Minnikin, D. E., M. D. Collins, and M. Goodfellow. 1979. Fatty acid and polar lipid composition in the classification of Cellulomonas, Oerskovia and related taxa. J. Appl. Bacteriol. 47:87-95.

25. Rainey, F. A., N. Ward-Rainey, R. M. Kroppenstedt, and E. Stackebrandt. 1996. The genus Nocardiopsis represents a phylogenetically coherent taxon and a distinct actinomycete lineage: proposal of Nocardiopsaceae fam. nov. Int. J. Syst. Bacteriol. 46:1088-1092.

26. Saitou, N., and M. Nei. 1987. The neighbour-joining method: a new method for reconstructing phylogenetic trees. Mol. Biol. Evol. 4:406-425.

27. Schleifer, K. H. 1985 . Analysis of the chemical composition and primary structure of murein. Methods Microbiol. 18:123-156.

28. Schleifer, K. H., and O. Kandler. 1972. Peptidoglycan types of bacterial cell walls and their taxonomic implications. Bacteriol. Rev. 36:407-477.

29. Schumann, P., H. Prauser, F. A. Rainey, E. Stackebrandt, and P. Hirsch 1997. Friedmanniella antarctica gen. nov., sp. nov., an LL-diaminopimelic acid-containing actinomycete from antarctic sandstone. Int. J. Syst. Bacteriol. 47:278-283.

30. Stackebrandt, E., C. Koch, O. Gvozdiak, and P. Schumann. 1995. Taxonomic dissection of the genus Micrococcus: Kocuria gen. nov., Nesterenkonia gen. nov., Kytococcus gen. nov., and Micrococcus Cohn 1872 gen. emend. Int J. Syst. Bacteriol. 45:682-692.

31. Stackebrandt, E., R. M. Kroppenstedt, and V. J. Fowler. 1983. A phylogenetic analysis of the family Dermatophilaceae. J. Gen. Microbiol. 129:18311838 .

32. Stackebrandt, E., F. A. Rainey, and N. L. Ward-Rainey. 1997. Proposal for a new hierarchic classification system, Actinobacteria classis nov. Int. J. Syst. Bacteriol. 47:479-491.

33. Stead, D. E., J. E. Sellwood, J. Wilson, and I. Viney. 1992. Evaluation of a commercial microbial identification system based on fatty acid profiles for rapid, accurate identification of plant pathogenic bacteria. J. Appl. Bacteriol. 72:315-321.

34. Tamura, T., Y. Nakagaito, T. Nishii, T. Hasegawa, E. Stackebrandt, and A Yokota. 1994. A new genus of the order Actinomycetales, Couchioplanes gen. nov., with descriptions of Couchioplanes caeruleus (Horan and Brodsky 1986) comb. nov. and Couchioplanes caeruleus subsp. azureus subsp. nov. Int. J. Syst. Bacteriol. 44:193-203.

35. Uchida, K., and K. Aida. 1984. An improved method for the glycolate test for simple identification for the acyl type of bacteria cell walls. J. Gen. Appl. Microbiol. 30:131-134.

36. Yamada, K., and K. Komagata. 1972. Taxonomic studies on coryneform bacteria. IV. Morphological, cultural, biochemical, and physiological characteristics. J. Gen. Appl. Microbiol. 18:399-416.

37. Yokota, A., M. Takeuchi, T. Sakane, and N. Weiss. 1993. Proposal of six new species of the genus Aureobacterium and transfer of Flavobacterium esteraromaticum Omelianski to the genus Aureobacterium as Aureobacterium esteraromaticum comb. nov. Int. J. Syst. Bacteriol. 43:555-564.

38. Yokota, A., T. Tamura, T. Hasegawa, and L. H. Huang. Catenuloplanes japonicus gen. nov., sp. nov., nom. rev., a new genus of the order Actinomycetales. Int. J. Syst. Bacteriol. 43:805-812. 